\title{
The influence school management and professional teachers motivation to the teachers in high school
}

\author{
Yustin Yuslah ${ }^{1}$, Bukman Lian $^{2}$, Syaiful Eddy $^{2}$ \\ ${ }^{1}$ Sekolah Menengah Atas Negeri 1Pedamaran, Indonesia \\ ${ }^{2}$ Universitas PGRI Palembang, Indonesia
}

\begin{tabular}{l} 
Article Info \\
\hline Article history: \\
Received Jul $17^{\text {th }}, 2021$ \\
Revised Aug $15^{\text {th }}, 2021$ \\
Accepted Aug $30^{\text {th }}, 2021$ \\
\hline
\end{tabular}

\section{Keyword:}

Motivation

Work

Teacher performance

\begin{abstract}
This research to know the politically charged raid aimed at school management and motivation of teachers professional high school teacher in kecamatan pedamaran.hipotesis asked in this research, management is the professional senior high school teachers in schools to pedamaran sub district, work is the motivation to performance in kecamatan pedamaran high school teacher, is the school management and motivation, working together on the same high school teacher in kecamatan pedamaran professional .In penilitian , hifotesis in use is the partial ) ( $\mathrm{t}$, the simultaneous ) ( $\mathrm{f}$, a correlation coefficient ( $\mathrm{r}$ ) ( $\mathrm{r} 2$ ) and coefficients determined. The results of the analysis supported survey data the results of the analysis and interview prove that there is influence professional school management to senior high school teachers in kecamatan pedamaran, influence motivation is work on performance senior high school teachers in kecamatan pedamaran, influence school management and motivation is work together to same professional senior high school teachers in kecamatan pedamaran with significant standard $\alpha<0,05$.
\end{abstract}

(C) 2021 The Authors. Published by IICET.

This is an open access article under the CC BY-NC-SA license (https://creativecommons.org/licenses/by-nc-sa/4.0

\section{Corresponding Author:}

Yuslah, Y.,

Sekolah Menengah Atas Negeri 1Pedamaran, Indonesia

Email: yustinyuslah75@gmail.com

\section{Introduction}

Teachers became one of the determining factor in whether the success of education, so that in carrying out their duties, need to have a set of the science of how should in educating a child or participants primary school students thus teachers is a component of education that is very dominant in the increase the quality of education. Learning so that quality where the teachers to qualified and professional.As teachers as having standard is professional by having particular qualification [1].

According to professional [4] members of a profession is the kind of commitment to enhance the capacity of profesionalism continuous and to develop the strategies used in making a job in accordance with their. It professionalism is intrinsic motivation from a teacher as a stimulant to develop itself at a professional. Teachers who have high professional will be reflected in the mental attitude and commitment to the embodiment and the improvement of professional in various ways and strategies in serving the needs of schooling.

Increased capacity professional can developed through professional competency done by teachers. A purpose capability to help teachers in professional teacher enlarge the knowledge of, improved the skills teachers, teaching who professional attitude in learning. So schools can take, a school principals and across 
teachers, colloquy or workshop, training or training, courses, formal education high as well as guidance and to support learning developtment which are effective for professional teacher ability.

School management is a crucial in supporting professional teachers .A variety of tasks hold by a mentor like mandated in various regulations explained how its strategic role of teachers in developing of the owned by students .In achieving its objectives the implementation of effective schools needed school management according to the conditions and the situation where schools was taken [2]. To school management, a principal or leader must give attention to the informal, symbolic aspect, and aspects that does not look of school life that shaped the belief and action every school .The strategy developed in the use of integrated quality management educational institutions in the world of education is positioned himself as institutions services in other words into a service industry .Providing service institutions desire customers. But school management , teacher motivation in carrying out their duties also affect professional teachers According to [3]

mentioned that motivation can be defined as the power of (energy someone who inflicts the level of persistence and her enthusiasm in melaksankan an activity whether they are from individual itself ( intrinsic motivation ) or from other individual 5 (Extrinsic motivation). By the presence of motivation on each be able to manage it is hoped that teacher learning well so can increase performance on individual teachers .

\section{Method}

This study research and design use of quantitative research study influence, shaped the influence between the third variable know the the independent variable or free school management (X1), motivate teachers (X2) and variable dependent or bound on teacher performance $(\mathrm{Y})$.The second set the $(\mathrm{X} 1)$ and $(\mathrm{Y})$ connected bound the variable with a pattern the relation between variables $\mathrm{X} 1$ with $\mathrm{Y}$, the relation between variables $\mathrm{X} 2$ with $\mathrm{Y}$ and relations together and he $\mathrm{x} x 1$ variable. Subject to this research is 105 one senior high school teachers subdistrict consisting of 44; the senior high school teachers negeri 1 Pedamaran teachers 1,22 , the union pedamaran high school 39 one senior high school teachers.Meranti pedamaran. Data collection in this study using a questionnaire, containing about school management (X1) motivation (X2) professional work and teachers $(Y)$. The questionnaire used previously undergone a validation and reliability beforehand .The results of the validation dairi known that the $r$ count all items about $\& \mathrm{gt}$; value $\mathrm{r}$ table, thus all about in this research considered valid and it is reliable .Pengujuan hypothesis to research it uses multiple linear regression, the model $t$ and feasibility study .

\section{Results and Discussions}

From the data analysis known to scatter data on this study normal distribution and one of multikolonieritas symptoms, heterokedastisitas autokorelasi, data is worth so in research to do the hypothesis.

\section{The influence of professional school management about a high school teacher in Pedamaran district}

T-hitung obtained value of $5.376<1,65978$ with probabilities a significant degree of $0,001<0,05$. While to yield linear regression he obtained the $=0.190+0.409 X 1$. From these figures means that significant professional school management to senior high school teachers in Pedamaran district.

\begin{tabular}{|c|c|c|c|c|c|c|}
\hline \multicolumn{7}{|c|}{ Coefficients $^{\mathrm{a}}$} \\
\hline \multirow{2}{*}{\multicolumn{2}{|c|}{ Model }} & \multicolumn{2}{|c|}{ Unstandardized Coefficients } & \multirow{2}{*}{$\frac{\text { Stand Coeff }}{\text { Beta }}$} & \multirow[b]{2}{*}{$\mathrm{t}$} & \multirow[b]{2}{*}{ Sig. } \\
\hline & & $\mathrm{B}$ & Std. Error & & & \\
\hline \multirow[t]{2}{*}{1} & (Constant) & .190 & .065 & & 2.310 & .103 \\
\hline & Manajemen Sekolah & .409 & .099 & .847 & 5.376 & .001 \\
\hline
\end{tabular}

a. Dependent Variable: Profesionalisme guru

\section{Influence Professional Motivate Teachers To Senior High School Teachers In Pedamaran district}

T-hitung obtained value of 6.503 gt \&; 1,65978 with probabilities a significant degree of $0,016<0,05$. While to yield linear regression he obtained the $=0.190+0.358 \mathrm{X} 2$. From these figures work means that significant profsionalisme motivation to high school in Pedamaran disctrct.

\begin{tabular}{cccccc}
\hline \multicolumn{6}{c}{ Coefficients $^{\mathbf{a}}$} \\
\hline \multirow{3}{*}{ Model } & \multicolumn{2}{c}{ Unstandardized Coefficients } & Stand Coeff & & \\
\cline { 2 - 5 } & B & Std. Error & Beta & t & Sig. \\
\hline
\end{tabular}




\begin{tabular}{|c|c|c|c|c|c|}
\hline 1 (Constant) & .190 & .065 & & 2.310 & .103 \\
\hline $\begin{array}{l}\text { Motivasi } \\
\text { Guru }\end{array}$ & .358 & .063 & .674 & 6.503 & .016 \\
\hline
\end{tabular}

a. Dependent Variable: Profesionalisme Guru

\section{Influence professional school management and motivation to senior high school teachers in kecamatan} pedamaran

From the determination obtained the value $\mathrm{r} 20836$ known that discipline and competence contributor \% 71,7 work on changes in on teacher performance. The $\mathrm{f}$ the shows $\mathrm{f}$ count gt $\& \mathrm{f} ;$ table and sig \& it 0,005 ;

\begin{tabular}{lrrrrr}
\hline \multicolumn{7}{c}{ Model Summary } \\
\hline Model & $\mathrm{R}$ & R Square & & Adjusted R Square & Std. Error of the Estimate \\
\hline 1 & $.847^{\text {a }}$ & .717 & & .413 & \\
\hline a. Predictors: (Constant), disiplin dan kompetensi & & & & \\
\hline
\end{tabular}

The influence of professionalism of the management of the schools to senior high school teachers in pedamaran district

This research result indicates that the management of school has influence significantly to professionalism in pedamaran teacher in high school, this is proven obtained from the statistical tests t-hitung value of $5,375<$ 1,663 with probability a significant degree of $0,001<0,05$ research results are consistent with previous research ever done Taryaman ( 2018: ) 118 , on the management of the schools to teachers in providing professional students achievement, indicating that school management influence positively and significantly to teachers in providing professional students achievement . Of annotations above, then the researcher would assume that schools that ability to handle and used on resources there will encourage teachers in performing a duty and functions optimally, to bring the purpose of the implementation of the education. Influence motivation professional guruterhadap teachers in high school kecamatan pedamaran. This research result indicates that the teachers have significant influence on pedamaran in professional teachers in high school, this is proven obtained from the statistical tests of the $t$--hitung 6.503 with probability a significant degree of 0,$016 ;<0,05 \&$ it .The results of the study are consistent with oernah research conducted by Eddy, S dkk (2020) in his study stated that teacher motivation is also a factor that influences the performance of teachers. Sadirman said success in his theory of an institution affected by various factors such, good and the coming from coming from outside educational institutions itself .Out of many factors the teachers ' work the motivation is one of the educational institutions itself .Out of many factors the teachers ' work the motivation is one of the educational institutions that very much determined success reach its objective.

Of annotations above, hence writers assume that teachers with high motivation work do a job by high spirits and use all abilities and skills and awareness that look in responsibility and implement work, dicapainya achievement, capacity building and independence in acting to get the employment leaving the cause of education and teaching can be achieved in accordance expected.

\section{Influence school management and professional motivate teachers to teachers in high school pedamaran district}

Based on the calculation on feasibility test model, obtained the $\mathrm{F}$ count of $18.579>\mathrm{F}$ the table 5,67 significantly by $0,000<0,05$. This indicates that the independent variable and motivate teachers, school management have had a positive impact on variables professional significant dependent teachers. Of the equation linear regression of berganda obtained $\mathrm{Y}=0.190+0.409 \mathrm{X} 1+0.358 \mathrm{X} 2+\mathrm{e}$.

Research is in line with the opinions Fitria , H (2019) stating that professional teachers will look through their responsibilities as a master in conduct all his devotion. Of annotations above, so the researchers assumed that a teacher professional reflected in having high mental attitude and and improving the quality of their commitment toward a professional in various ways and strategies. 


\section{Conclusions}

The research called the school management and motivation of teachers professional teachers in high school in pedamaran, it can be concluded as follows,

(1) There an effect of school management (X1) There an effect professional teachers (Y ) .

(2) Motivate teachers for teacher profesional (X2) There an effect professional teachers (Y)

(3) School management ( ) motivate teachers ( $\mathrm{x} 1$ and $\mathrm{x} 2$ ) simultaneously teacher professional (y)

\section{References}

Bahri, Syamsul. (2015). Faktor yang mempengaruhi kinerja guru SD di Dataran Tinggi Moncong Gowa. Jurnal MEDTEK, volume 3, nomor 2 Oktober

Arikunto, Suharsimi. (2016). Manajemen pengajaran secara manusiawi. Jakarta: Rinekacipta

Kompri. (2015). Motivasi Pembelajaran Perspektif Guru dan Siswa. Bandung: PT. Remaja Rosdakarya Offset Danim. (2008). Kinerja Staf dan Organisasi, Jakarta: CV. Pustaka Setia. 